\title{
Bryophyte flora of Gayasan Mountain National Park in Korea
}

\author{
Hyun Min BUM, Eun-Young YIM ${ }^{1}$, Seung Jin PARK, Vadim A. BAKALIN ${ }^{2}$, \\ Seung Se CHOI ${ }^{* *}$, Sea-Ah RYU ${ }^{4}$ and Chang Woo HYUN ${ }^{4}$ \\ Department of Life Science, Jeonbuk National University, Jeonju 54896, Korea \\ ${ }^{1}$ Warm Temperate and Subtropical Forest Research Center, National Institute of Forest Science, Seogwipo 63582, Korea \\ ${ }^{2}$ Botanical Garden-Institute, Vladivostok 690024, Russia \\ ${ }^{3}$ Team of National Ecosystem survey, National Institute of Ecology, Seocheon 33657, Korea \\ ${ }^{4}$ Plant Resources Division, National Institute of Biological Resources, Incheon 22755, Korea \\ (Received 1 February 2021; Revised 1 March 2021; Accepted 12 March 2021)
}

\begin{abstract}
We investigated the bryophyte flora of the Gayasan Mountain National Park in Korea by conducting 18 field surveys in from April of 2009 to November of 2016 at various sites on the mountains. During the surveys, we discovered 204 taxa comprising 57 families, 106 genera, 199 species, 2 subspecies, and 3 varieties. Among these, 145 species were reported as new to the flora of Gayasan Mountain. A checklist based on a study of 903 specimens is provided. The most notable species recorded during the surveys were the rare bryophytes Hattoria yakushimensis (Horik.) R. M. Schust., Nipponolejeunea pilifera (Steph.) S. Hatt., Drepanolejeunea angustifolia (Mitt.) Grolle, Lejeuena otiana S. Hatt., Cylindrocolea recurvifolia (Steph.) Inoue and Pogonatum contortum (Menzies ex Brid.) Lesq.
\end{abstract}

Keywords: Bryophyte, flora, mosses, liverworts, Gayasan Mt.

The first of bryophytes on Gayasan Mountains was published by Kashimura (1939) who identified two species, Andreaea rupestris var. fauriei (Besch.) Takaki. and Rhizomnium punctatum (Hedw.) T. J. Kop. collected on 24 September 1938. Since that time, the bryophyte flora of the Gayasan Mountain has been surveyed and also included in inventories of mosses and liverworts of the Korean Peninsula published on 20 species by Hong (1966) and 12 species Choe (1980). However, only 38 taxa were reported in these and other old studies, and more recently, Song and Yamada (2009) have reported on 38 taxa of liverworts. In the present study, we conducted the first comprehensive survey of bryophyte species distributed in the Gayasan Mountain National Park, with the aim of providing basic data that will contribute to establishing a conservation plan for the bryophyte flora of this parks.

Gayasan Mountain, designated Korea's 9th national park in Korea in 1972, covers a total area of $77 \mathrm{~km}^{2}$, and borders the Hapcheon-gun and Geochang-gun of Gyeongsangnam-do and Seongju-gun of Gyeongsangbuk-do. The mountain lies between latitudes and longitudes $35^{\circ} 44^{\prime} 56^{\prime \prime}-35^{\circ} 51^{\prime} 19^{\prime \prime} \mathrm{N}$ and $128^{\circ} 02^{\prime} 42^{\prime \prime}-128^{\circ} 11^{\prime} 10^{\prime \prime} \mathrm{E}$, the lowland area of which has a mean annual temperature of $13.4^{\circ} \mathrm{C}$ and precipitation of $1,276 \mathrm{~mm}$ per year (Korea Meteorological Administration, 2019). The highest ridges of the mountain are Sangwangbong (1,430 meters above sea level [m a.s.l.], the main peak), Chilbulbong (1,433 m a.s.1.), and Dongseongbong (1,227 m a.s.1.). The Gayasan Mountain valley's area (Hongnyudong and Baegundong valleys) comprises mainly granite and is noted for its numerous historical and scenic sites, including the Haeinsa Temple and Palmandaejanggyeong (Buddhist Scriptures) (Choi and Do, 2016). The geology of Gayasan Mountain is mainly composed of Precambrian biotite gneiss, semi-phalangeal gneiss, Ileal rock, and Haeinsa granite formed during the Cretaceous period (Lee et al., 2016). In addition, approximately $85.2 \%$ of the total area of Gayasan Mountain National Park lies at elevations higher than $600 \mathrm{~m}$ a.s.l., whereas $10.3 \%$ of the area exceeds $1,000 \mathrm{~m}$ a.s.l, and is characterized by a mixture of plants with distribution ranges

\footnotetext{
*Author for correspondence: hepaticae@jbnu.ac.kr
} 
in the southern and central regions of the Korean Peninsula (Myeong et al., 2016). The ridgeline area is also rich in rocky outcrops and there are occasional area of gravelly barren fields on the steep slopes.

\section{Materials and Methods}

Field surveys

Our collections were carried out in habitats with a high

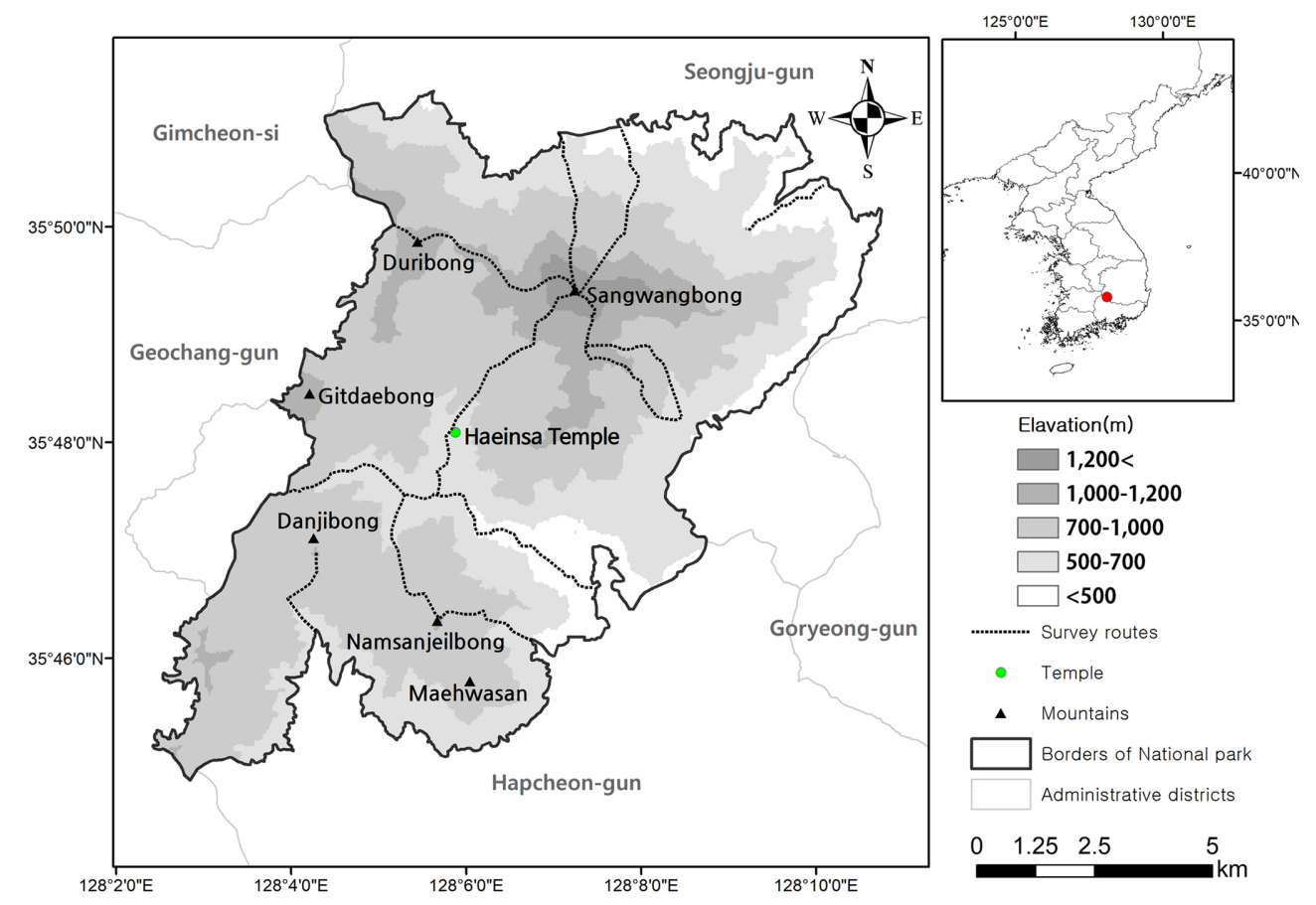

Fig. 1. The position of Gayasan Mountain within Korean Peninsula and the surveyed routes in this study.
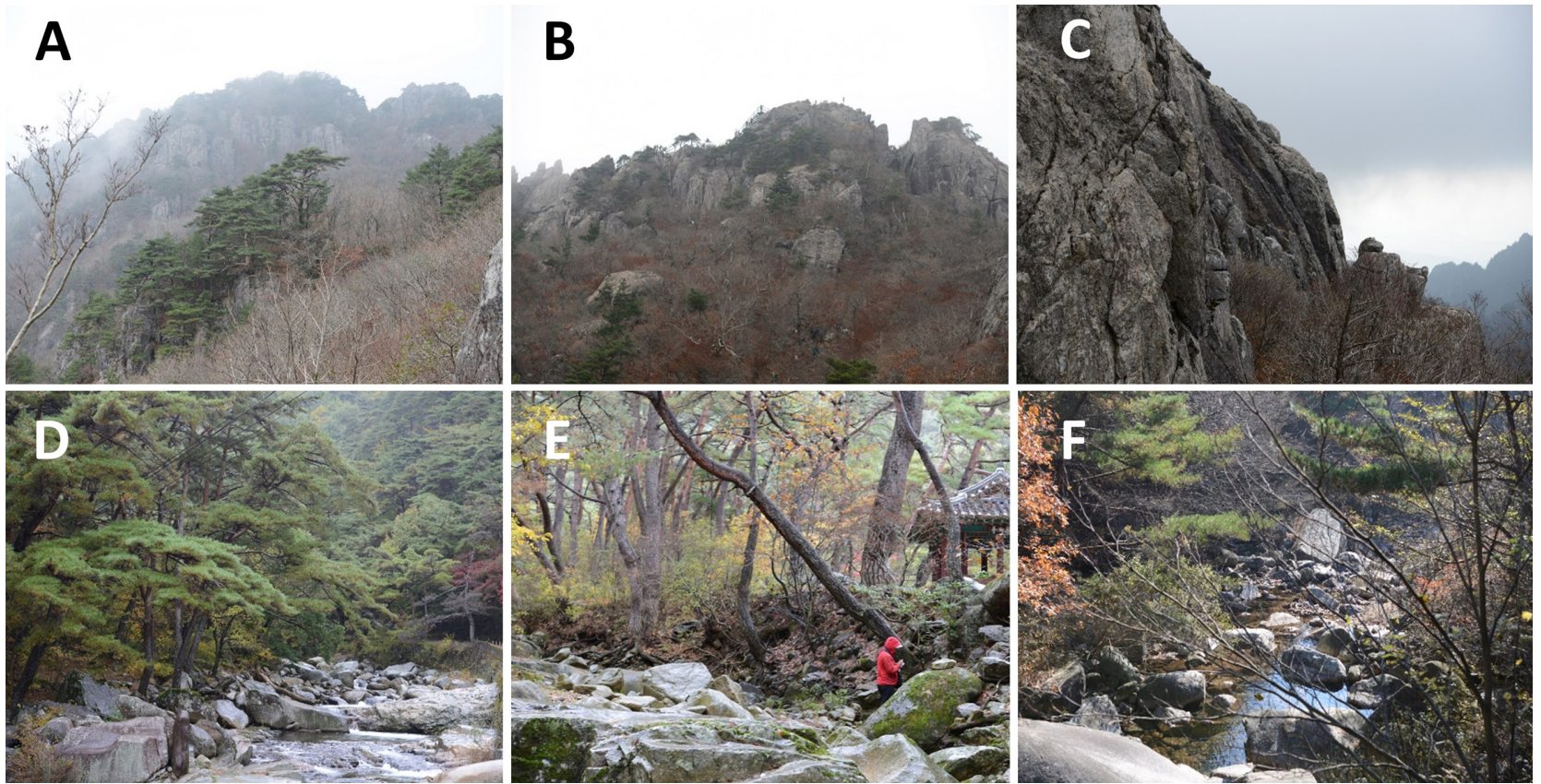

Fig. 2. Habitats of Gayasan Mountain. A. Sangwangbong (peak). B. Northern slope of Sangwangbong. C. Cliffs near Sangwangbong. D. Low part of Hongryudong valley. E. Middle part of Hongryudong valley. F. Baegundong valley. 
Table 1. Surveyed locals and dates of Gayasan Mountain.

\begin{tabular}{|c|c|c|}
\hline No. & Localities & Dates \\
\hline & Hongryudong valley & 28 Apr 2009 \\
\hline & Hongryudong valley-Sangwangbong (peak) & 8 Sep 2009 \\
\hline & Hongryudong valley-Sangwangbong (peak) & 22 Jun 2010 \\
\hline & Hongryudong valley, Yonggi valley & 29-30 Mar 2016 \\
\hline & Masu valley, Sangseonbul & 18 May 2016 \\
\hline & $\begin{array}{l}\text { Hongryudong valley, Geumbawi valley, } \\
\text { Gitdaebong }\end{array}$ & 26-28 May 2016 \\
\hline & Haeinsa temple-Hongjeam-Gwaneumgol & 10 Jun 2016 \\
\hline & Nakwhadam area & 30 Jun 2016 \\
\hline & Youngmoon waterfall area & 7 Jun 2016 \\
\hline & Haeinsa temple-Tosimgol & 10 Aug. 2016 \\
\hline & Samjeong camp, Chiin camp & 16-17 Aug. 2016 \\
\hline & Hongryudong valley, Yungmun waterfall & 23-25 Sep 2016 \\
\hline & Haeinsa temple-Sangwangbong (peak) & $8-9$ Oct 2016 \\
\hline & Yonggigol valley & $10-14$ Oct 2016 \\
\hline \multicolumn{3}{|c|}{$\begin{array}{l}15 \text { Hongryudong valley, Sangwangbong (peak), } \\
\text { Yonggi valley }\end{array}$} \\
\hline & Seoseongjae & 4-5 Nov. 2016 \\
\hline & Seokgyedong valley & 18-20 Nov 2016 \\
\hline & Maehwasan valley & 25-27 Nov 2016 \\
\hline
\end{tabular}

diversity of bryophytes, such as wet habitats near stream beds, more or less dry rocks, bark of forest trees, and exposed stony fields and shaded cliffs near some mountain tops (Figs. $1,2)$. We conducted a total of 18 field surveys from April 2009 to November 2016 at various sites in the park (Table 1).

All specimens were collected in newspaper or acid-free paper, and collection date, geographical coordinates, field herbarium numbers, collector names, preliminary species name, substrates, and habitats were recorded in the field. The collected materials were air-dried in the laboratory, and some species were cultivated in the greenhouse. All specimens were deposited in the Jeonbuk National University Herbarium (JNU) and National Institute of Biological Resources Herbarium (KB).

\section{Latitude and longitudinal fractional composition}

The treatment of latitudinal and longitudinal types basically follows to Konstantinova (2000) and Bakalin (2010). The distribution of each species was identified in a threedimensional grid, from the Arctic to Tropical, from East Asian to Circumpolar, and its tendency to be distributed in mountainous areas. Nine latitudinal types of elements and eleven longitudinal types of habitat (area types) were identified to classify the distribution species. For the analysis of the distribution characteristics of bryophytes, their world distribution was obtained from Noguchi (1987, 1988, 1989, 1991, 1994), Gao et al. (1999, 2003), Lawton (1999), Li et al. (2001, 2007), Wu et al. (2002, 2005, 2011), Hu et al. (2008), and Korean distribution was obtained from Choe (1980), Kim and Hwang (1991), Kim (1991), and Bakalin (2010), Park (2020).

\section{Number of bryophyte taxa and liverwort index}

The liverwort index, which is based on the character that liverworts and hornworts tend to prefer more humid conditions than mosses do, was calculated as follows (Nakanishi, 2001):

Liverwort index $(\%)=\frac{\begin{array}{c}\text { Number of liverworts } \\ + \text { number of hornworts }\end{array}}{\text { The total number of bryophytes }} \times 100$

\section{Results and Discussion}

\section{Bryophyte flora}

On the basis of an inspection of 903 herbarium specimens, we found that the bryophyte flora of the Gayasan Mountain includes 204 taxa belonging to 57 families, 106 genera, 199 species, 2 subspecies, and 3 varieties (Table 2). Among these, there were 115 taxa of Bryophyta (33 families, 67 genera, 111 species, 2 subspecies, and 2 varieties) and 89 taxa of Marchantiophyta (24 families, 39 genera, 88 species, and 1 variety). This is equivalent to $18.1 \%$ of the 1,121 taxa (346 liverworts and 775 mosses) recorded on the Korean Peninsula (Kim et al., 2020). Among the species identified, 145 taxa are newly recorded in the Gayasan Mountain (Appendix 1).

\section{Comparison of bryophyte species richness and liverwort indices}

Compared with recently studied bryophyte flora [Taebaeksan Mountain (Bum et al., 2020), Deogyusan Mountain (Yoon et al., 2011; Choi et al., 2013), Hallasan Mountain (Yim, 2012), and Sobaeksan Mountain (Choi et al., 2016)], Gayasan Mountain is characterized the lowest number of species (204 species), although the second highest number of taxa (2.67) on an area basis. The comparatively small number of species can be ascribed to the fact that although the Gayasan Mountain includes a variety of habitats, including different parent rocks (Precambrian biotite gneiss, semi-phalangeal gneiss, Ileal rock, and Cretaceous Haeinsa granite), some coniferous forests near the peaks, and small and 
Table 2. Summary of Bryophyte flora of Gayasan Mountain National Park.

\begin{tabular}{lcccccc}
\hline \hline & Families & Genera & Species & Subsp. & Var. & Taxa \\
\hline Marchantiophyta & 24 & 39 & 88 & - & 1 & 89 \\
Bryophyta & 33 & 67 & 111 & 2 & 2 & 115 \\
Total & 57 & 106 & 199 & 2 & 3 & 204 \\
\hline
\end{tabular}

Table 3. Comparison of the bryophyte species richness levels and liverwort indexes in other localities and Gayasan Mountain National Park.

\begin{tabular}{lccccc}
\hline \hline & Gayasan Mt. & Taebaeksan Mt. & Hallasan Mt. & Deogyusan Mt. & Sobaeksan Mt. \\
\hline Area $\left(\mathrm{km}^{2}\right)$ & 76.25 & 70.05 & 153.33 & 231.65 & 322.01 \\
No. of taxa & 204 & 274 & 378 & 311 & 236 \\
Mosses & 115 & 167 & 253 & 184 & 137 \\
Liverworts & 89 & 107 & 125 & 127 & 99 \\
Liverwort index $(\%)$ & 43.6 & 39.0 & 33.1 & 40.8 & 41.9 \\
No. of taxa/Area $\left(\mathrm{km}^{2}\right)$ & 2.67 & 3.91 & 2.47 & 1.35 & 0.74 \\
\hline
\end{tabular}

large valleys (the Hongryudong and Baegundong valleys), the area cover covered in relatively small. Furthermore, according to the liverwort index, which indicates the degree of humidity in a surveyed area, Gayasan Mountain (43.6\%) was found to be the wettest among the aforementioned areas (Sobaeksan Mountain 41.9\%, Deogyusan Mountain 40.8\%, and Taebaeksan Mountain 39.0\%) (Table 3).

\section{The latitudinal and longitudinal distribution of floristic elements among bryophytes of the Gayasan Mountain}

Analysis of floristic elements based on latitude (Table 4) revealed that 54 taxa $(26.5 \%)$ are boreal temperate, $45(22.1 \%)$ temperate, 39 (19.1\%) temperate-subtropical, 20 (9.8\%) multizonal, 14 (6.9\%) subtropical, 11 (5.4\%) subtropicaltropical, 9 (4.4\%) boreal, 8 (3.9\%) arctic-boreal, and 4 (1.9\%) arctic species. Compared with the latitudinal distribution characteristics of the Korean Peninsula bryophyte flora, the bryophyte flora of the Gayasan Mountain is characterized by temperate-subtropical $(+6.5 \%)$ and temperate $(+1.4 \%)$ taxa, and the lowest numbers of boreal temperate taxa $(-2.1 \%)$ and subtropical $(-1.8 \%)$, boreal $(-1.6 \%)$, arctic-boreal $(-1.4 \%)$, subtropical-tropical (-0.5\%), arctic (-0.4\%), and multizonal ($0.1 \%$ ) species. It is assumed that these distribution patterns are attributable to the geographical location of the Gayasan Mountain, as well as increases in the numbers of temperatesubtropical and temperate plants in the lower regions of the valleys within the Gayasan Mountain range.

Analysis of the floristic elements based on longitude (Table 5) indicated that 84 taxa $(41.2 \%)$ are of Eastern Asian distribution, 48 (23.5\%) circumpolar, 24 (11.8\%) multi-areal,
9 (4.4) Eastern Asia-American, 7 (3.4\%) Asia-American, 4 (1.2) Asia-Europe and Amphipacific, and 3 (1.5\%) Amphioceanic, with a further single species $(0.5 \%)$ showing a disjunctive distribution. Compared with the longitudinal distribution characteristics of the Korean Peninsula bryophyte flora, that of the Gayasan Mountain is characterized by Eastern Asian and Asia-American (+1.9\%), Asia-European (+1.4\%), Amphipacific ( +0.8$)$, Eastern Asia-American $(+0.7)$, and Asian mult-iareal $(+0.6)$ taxa, with the lowest numbers of Circumpolar taxa $(-5.3 \%)$, and disjunctive (-1.6\%), Amphioceanic (-0.7\%), and Southeast Asian (-0.1\%) species. These findings thus clearly indicate that the flora of the Gayasan Mountain region of the Korean Peninsula is of an Eastern Asian type (Takhtajan, 1986).

\section{Comparisons with previous studies on the bryophyte flora of the Gayasan Mountain}

The Gayasan Mountain were included in the areas investigated as part of an inventory of mosses distributed in the Korean Peninsula conducted by Kashimura (1939, 1940), who published a checklist on Korean mosses, which included 15 taxa (Andreaea rupestris var. fauriei, Pogonatum inflexum, Bryoxiphium norvegicum subsp. japonicum, Bryum argenteum, Plagiomnium acutum, Rhizomnium punctatum, Hedwigia ciliata, Boulaya mittenii, Myuroclada maximowiczii, Meteorium buchananii subsp. helminthocladulum, Rhytidium rugosum, Entodon flavescens, Homalia trichomanoides, Eumyurium sinicum, Anomodon rugelii) recorded in the Gayasan Mountain. Subsequently, Choe (1980) published a manual on Korean Bryophytes, which included 12 taxa (Andreaea rupestris var. fauriei, Hedwigia ciliata, Eumyurium sinicum, 
Table 4. The latitude fractional composition in Gayasan Mountain with Korean Bryophyte.

\begin{tabular}{|c|c|c|c|c|c|}
\hline \multirow{2}{*}{$\begin{array}{l}\text { Floristic elements } \\
\text { (latitudinal types) }\end{array}$} & \multicolumn{2}{|c|}{ Taxa } & \multicolumn{3}{|c|}{ Percentages } \\
\hline & Korea & Gayasan Mt. & Korea & Gayasan Mt. & Comparison \\
\hline Arctic & 24 & 4 & 2.3 & 1.9 & -0.4 \\
\hline Arctic-boreal & 55 & 8 & 5.3 & 3.9 & -1.4 \\
\hline Boreal & 62 & 9 & 6.0 & 4.4 & -1.6 \\
\hline Boreal-temperate & 295 & 54 & 28.6 & 26.5 & -2.1 \\
\hline Temperate & 214 & 45 & 20.7 & 22.1 & 1.4 \\
\hline Temperate-subtropical & 130 & 39 & 12.6 & 19.1 & 6.5 \\
\hline Subtropical & 90 & 14 & 8.7 & 6.9 & -1.8 \\
\hline Subtropical-tropical & 61 & 11 & 5.9 & 5.4 & -0.5 \\
\hline Multizone & 102 & 20 & 9.9 & 9.8 & -0.1 \\
\hline Total & 1,033 & 204 & 100 & 100 & 0 \\
\hline
\end{tabular}

Table 5. The latitude fractional composition in Gayasan Mountain with Korean Bryophyte.

\begin{tabular}{|c|c|c|c|c|c|}
\hline \multirow{2}{*}{$\begin{array}{l}\text { Floristic elements } \\
\text { (longitudinal types) }\end{array}$} & \multicolumn{2}{|c|}{ Taxa } & \multicolumn{3}{|c|}{ Percentages } \\
\hline & Korea & Gayasan Mt. & Korea & Gayasan Mt. & Comparison \\
\hline Amphioceanic & 23 & 3 & 2.2 & 1.5 & -0.7 \\
\hline Amphipacific & 12 & 4 & 1.2 & 2.0 & 0.8 \\
\hline Asia & 95 & 20 & 9.2 & 9.8 & 0.6 \\
\hline Asia-American & 16 & 7 & 1.5 & 3.4 & 1.9 \\
\hline Asia-Europe & 6 & 4 & 0.6 & 2.0 & 1.4 \\
\hline Circumpolar & 298 & 48 & 28.8 & 23.5 & -5.3 \\
\hline Disjunctive & 22 & 1 & 2.1 & 0.5 & -1.6 \\
\hline Eastern Asia & 406 & 84 & 39.3 & 41.2 & 1.9 \\
\hline Eastern Asia-American & 38 & 9 & 3.7 & 4.4 & 0.7 \\
\hline Southeastern Asia & 1 & 0 & 0.1 & 0.0 & -0.1 \\
\hline Multiarea & 116 & 24 & 11.2 & 11.8 & 0.6 \\
\hline Total & 1,033 & 204 & 100 & 100 & 0 \\
\hline
\end{tabular}

Anomodon giraldii, Anomodon rugelii, Boulaya mittenii, Trichocoleopsis sacculata, Jungermannia exsertifolia subsp. cordifolia, Plagiochila hakkodensis, Cephaloziella spinicaulis, Frullania diversitexta, Frullania inflata) recorded in the Gayasan Mountain, whereas Hong (1966) reported 20 taxa on Gayasan Mountain as part of an inventory of the liverworts of the Korean Peninsula. The first of the surveys described herein conducted by Song and Yamada (2009) focused on liverworts, during which 38 taxa were recorded, two (Frullania aoshimensis and Radula oyamensis) of which were recorded from the Korean Peninsula for the first time. A further analysis of records in the previous literature raised the total number of taxa to 58 , and on the basis of subsequent literature and survey studies, the total number of taxa currently stands at 204 (115 mosses and 89 liverworts).

\section{Notable species}

The most noteworthy species identified during the course of surveying are Hattoria yakushimensis (Horik.) R. M. Schust., Nipponolejeunea pilifera (Steph.) S. Hatt., Drepanolejeunea angustifolia (Mitt.) Grolle, and Lejeunea otiana S. Hatt. which are rarely found in Korea, as well as Cylindrocolea recurvifolia (Steph.) Inoue, the population size of which on Gayasan Mountain is the largest among those recorded to date on Korean Mountains. Additionally, a further notable species is Pogonatum contortum (Menzies ex Brid.) Lesq., a 

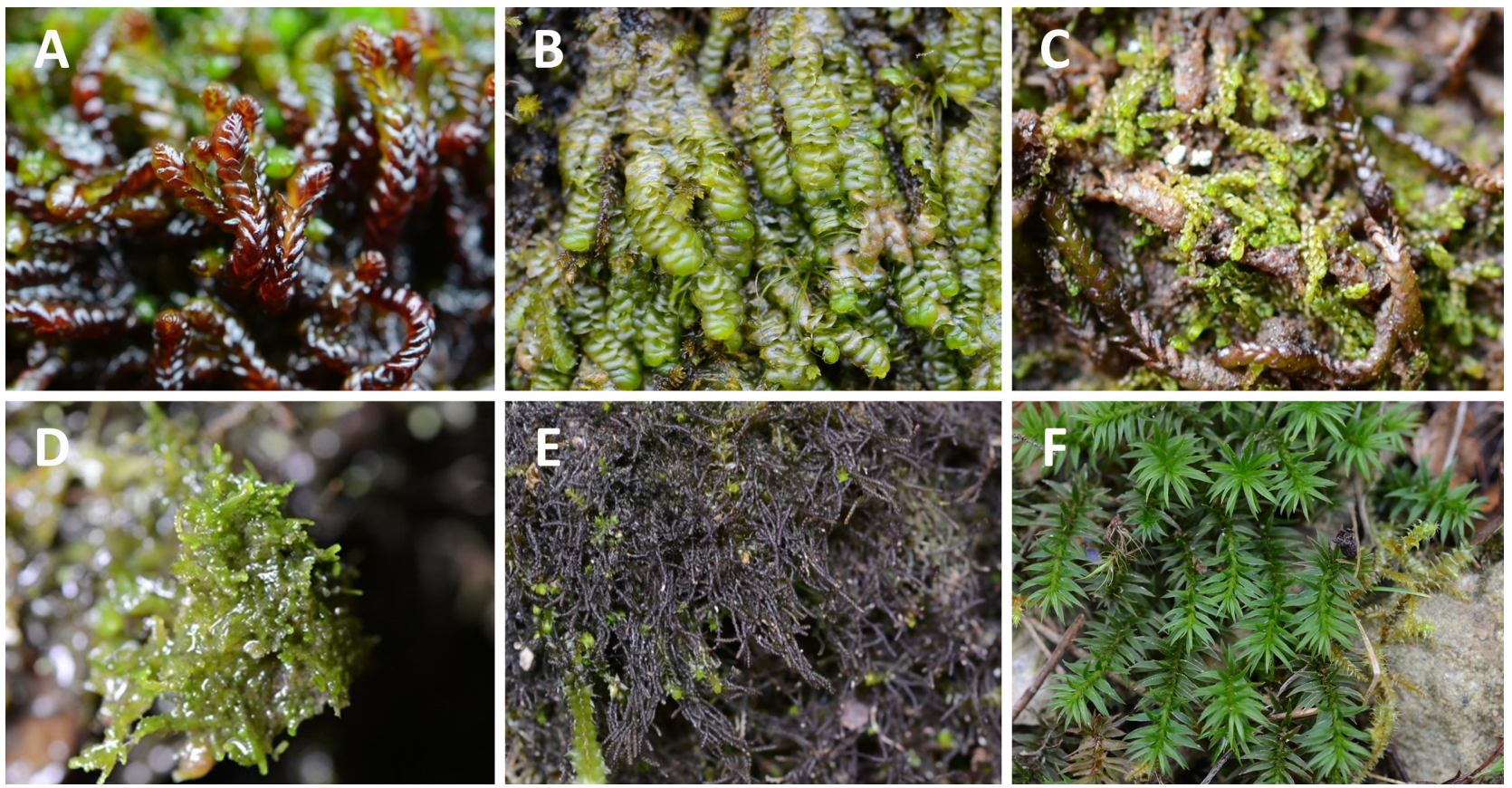

Fig. 3. Notable species of Gayasan Mountain in Korean flora. A. Hattoria yakushimensis (Horik.) R. M. Schust. B. Nipponolejeunea pilifera (Steph.) S. Hatt. C. Drepanolejeunea angustifolia (Mitt.) Grolle. D. Lejeuena otiana S. Hatt. E. Cylindrocolea recurvifolia (Steph.) Inoue. F. Pogonatum contortum (Menzies ex Brid.) Lesq.

rare bryophyte that grow in high-altitude areas (in excess of 1,000 m) (Fig. 3).

Hattoria yakushimensis was previously reported near the Sangwangbong Peak of Gayasan Mountain as a hitherto unrecorded species in Korea (Choi et al., 2011). This species is endemic to East Asia with a narrow distribution range (Japan and China) and is listed by the International Union for Conservation of Nature as a vulnerable (VU) species. In the present study, we also found H. yakushimensis on a cliff near the peak at an elevation of 1,313-1,350 m, where it grows with Drepanolejeunea angustifolia, Plectocolea erecta, and Marsupella tubulosa.

Nipponolejeunea pilifera, which is characterized by long cilia along the leaf dorsal lobe margin, is sparsely distributed in Japan, China, and the southernmost Russian Far East. In Korea, it has previously been recorded in Deogyusan Mountain and Jirisan Mountain (Choi et al., unpubl. data). In the present study, we found it on the edge of Abies koreana E. H. Wilson forest near the northern face between the peaks Sangwangbong and Chilbulbong. This species grows with Frullania appendiculata, Frullania usamienesis, and Bazzania denudata.

Drepanolejeunea angustifolia is mainly distributed in subtropical and tropical regions (Bhutan, Cambodia, China, India, Indonesia, Japan, New Caledonia, Papua New Guinea,
The Philippines, Sri Lanka, Thailand, and Vietnam) (Zhu and So, 2001). This bryophyte was previously reported near the Sangwangbong peak of Gayasan Mountain as an unrecorded species in Korea and has more recently been found in Jirisan Mountain, Hallasan Mountain, and Sobaeksan Mountain (Choi et al., 2012; Choi et al., unpubl. data). It is characterized by bifid underleaves, curved entire leaf margins, and 1 to 2 ocelli in the dorsal leaf lobe base, and found on shaded wet cliffs covering thin soil, along with Plectocolea erecta, Marsupella tubulosa, and Hattoria yakushimensis.

Lejeunea otiana has previously been collected in small caves near the Hongryudong Valley of Gayasan Mountain, at the time of which it was an unrecorded species in Korea (Choi et al., 2012). This species is distributed in Japan and the Korean islands of Jejudo and Gageodo (Choi et al., unpubl. data). In the present study, we also found specimens in a small cave in the same area. This species grows on shaded wet cliffs along with Acanthocoleus yoshinaganus, Conocephalum salebrosum, and Conocephalum japonicum.

Cylindrocolea recurvifolia is distributed in Eastern Asian temperate regions (Japan and China), southward spreading to Indochina, and in Korea has previously been recorded in the Seolaksan, Gyeryongsan, Naejangsan, Naebyeonsan, Duryunsan, and Weolchulsan mountains and the islands of Oerarodo and Jejudo, However, the patches found near the Hongryudong 
Valley in the present study are, of the largest size of our knowledge, the largest that have been recorded to date. We accordingly believe that it is necessary to promote, protect, and appropriately manage the Hongryudong Valley, for example, by installing information boards in this area.

Pogonatum contortum is distributed in Eastern AsiaAmerican temperate regions (Japan, China, India, Far East Russia, and North America) and the Keumgangsan, Seolaksan, Jirisan, and Hallasan regions of Korea at elevations greater than $1,000 \mathrm{~m}$. We found it growing on slightly shaded wet soil near the northern face running from between the peaks of Sangwangbong and Chilbulbong. This species is characterized by a deep green foliage, the leaves of which are slightly curved when dried.

ORCID: Hyun Min BUM http://orcid.org/0000-0001-75180702; Eun-Young YIM https://orcid.org/0000-0002-3733-4798; Seung Jin PARK https://orcid.org/0000-0002-7967-8361; Vadim BAKALIN http://orcid.org/0000-0001-7897-4305; Seung Se CHOI https://orcid.org/0000-0002-3332-5544; Chang Woo HYUN http://orcid.org/0000-0001-9677-5270;

\section{Acknowledgments}

The work was supported by the grant "Biological Diversity Survey of the Flora of Korean Bryophyta (NIBR201902104)" from the National Institute of Biological Resources of Ministry of Environment in Korea to C.W. Hyun. The work of Bakalin was partially supported by grants from the Russian Foundation for Basic researches (20-04-00278).

\section{Conflict of Interest}

The authors declare that there are no conflicts of interest.

\section{Literature Cited}

Bakalin, V. A. 2010. Hepaticae of the Kuril Islands (Northwestern Pacific): a transoceanic route from Circumboreal to East Asian flora. Annales Botanici Fennici 47: 81-105.

Bum, H. M., S. J. Park, V. A. Bakalin, B. Choi, S. H. Sim, C. W. Hyun and S. S. Choi. 2020. Bryophyte flora of Taebaeksan Mountain National Park in Korea. Korean Journal of Plant Taxonomy 50: 262-278.

Choe, D. M. 1980. Illustrated Flora and Fauna of Korea. Vol. 24. Musci-Hepaticae. Ministry of Education, Seoul, 790 pp. (in Korean)

Choi, S. D. and J. G. Do. 2016. The general present condition of
Gayasan Mountain. In Natural Resources Survey of Gayasan National Park. Korea National Park Research Institute, Wonju. Pp. 9-18. (in Korean)

Choi, S. S., V. A. Bakalin and B.-Y. Sun. 2013. Hepatics of Mt. Deogyu National Park, Republic of Korea. Botanical Pacifica 2: 63-71.

Choi, S.-S., V. A. Bakalin, C.-H. Kim and B.-Y. Sun. 2011. Unrecorded liverwort species from Korean flora: Alobiellopsis parvifolius (Cephaloziaceae), Calypogeia japonica (Calypogeiaceae), Hattoria yakushimensis (Lophoziaceae), Nardia subclavata (Solenostomataceae). Korean Journal of Plant Taxonomy 41: 230-234.

Choi, S. S., V. A. Bakalin, C.-H. Kim and B.-Y. Sun. 2012. Six unrecorded species from the family Lejeuneaceae (Marchantiophyta) in Korea. Korean Journal of Plant Taxonomy 42: $150-156$.

Choi S. S., S. J. Park, N. R. Yun and B. M. Bum. 2016. Flora of Bryophytes. In 2016 Natural Resources Survey of Sobaeksan National Park. National Park Research Institute, Korea National Park, Wonju, 788 pp. (in Korean)

Crandall-Stotler, B., R. E. Stotler and D. G. Long. 2009. Morphology and classification of the Marchantiophyta. In Bryophyte Biology. Goffinet, B. and A. J. Shaw (eds.), Cambridge University Press, Cambridge, NY. Pp. 1-54.

Gao C., M. R. Crosby and H. Si. 1999. Moss Flora of China, Vol. 1. Sphagnaceae-Leucobryaceae. Science Press, Beijing and Missouri Botanical Garden Press, St. Louis, MO, 139 pp.

Gao, C., M. R. Crosby and H. Si. 2003. Moss Flora of China, Vol. 3. Grimmiaceae-Tetraphidaceae. Science Press, Beijing and Missouri Botanical Garden Press, St. Louis, MO, 141 pp.

Goffinet, B., W. R. Buck and A. J. Show. 2009. Morphology and classification of the Bryophyta. In Bryophyte Biology. Goffinet, B. and A. J. Shaw (eds.), Cambridge University Press, Cambridge, NY. Pp. 55-138.

Hong, W. S. 1966. The leafy Hepaticae of South Korea and their phytogeographic relationships, especially to the flora of North America. The Bryologist 69: 393-426.

Hu, R.-L., Y.-F. Wang, M. R. Crosby and H. Si. 2008. Moss Flora of China, Vol. 7. Amblystegiaceae-Plagiotheciaceae. Science Press, Beijing and Missouri Botanical Garden Press, St. Louis, MO, $258 \mathrm{pp}$.

Kashimura, I. 1939. General enumeration of mosses from Korea. Journal of Chosen Natural History Society 26: 7-19.

Kashimura, I. 1940. General Enumeration of Mosses from Korea. (II). Journal of Chosen Natural History Society 30: 60-71.

Kim, Y. H. 1991. Korean Spore Plant 9 (Moss). Publishing House of Science on Encyclopodia, Pyeongyang, 391 pp. (in Korean)

Kim, Y. H. and H. J. Hwang. 1991. Korean Spore Plant 8 (Hepat- 
icae). Publishing House of Science on Encyclopodia, Pyeongyang, 223 pp. (in Korean)

Kim, W., M. Higuchi and T. Yamaguchi. 2020. An updated list of mosses of Korea. Journal of Species Research 9: 377-412.

Konstantinova, N. A. 2000. Distribution patterns of the North Holarctic hepatics. Arctoa 9: 29-94. (in Russian)

Lawton, E. 1971. Moss Flora of the Pacific Northwest. Hattori Botanical Laboratory, Miyazaki. 362 pp.

Lee J. K., C. O. Choo and S. H. Lee. 2016. Geography of Gayasan Mountain. In Natural Resources Survey of Gayasan National Park. Korea National Park Research Institute, Wonju. Pp. 1976. (in Korean)

Li, X. J., M. R. Crosby and H. Si. 2001. Moss Flora of China, Vol. 2. Fissidentaceae-Ptychomitriaceae. Science Press, Beijing and Missouri Botanical Garden Press, St. Louis, MO, 283 pp.

Li, X. J., M. R. Crosby and H. Si. 2007. Moss Flora of China, Vol. 4. Science Press, Beijing and Missouri Botanical Garden Press, St. Louis, MO, 211 pp.

Myeong, H. H., J. Y. Lee, J. H. Lee and J. Y. Kim. 2016. Vegetation of Gayasan Mountain. In Natural Resources Survey of Gayasan National Park. Korea National Park Research Institute, Wonju, Korea. Pp. 77-100. (in Korean)

Nakanishi, K. 2001. Floristic diversity of bryophyte vegetation in relation to island area. The Journal of the Hattori Botanical Laboratory 91: 301-316.

Noguchi, A. 1987. Illustrated Moss Flora of Japan 1. Daigaku Printing Co., Ltd., Hirisima. Pp. 1-242.

Noguchi, A. 1988. Illustrated Moss Flora of Japan 2. Daigaku Printing Co., Ltd., Hirisima. Pp. 243-491.

Noguchi, A. 1989. Illustrated Moss Flora of Japan 3. Daigaku Printing Co., Ltd., Hirisima. Pp. 493-742.

Noguchi, A. 1991. Illustrated Moss Flora of Japan 4. Daigaku Printing Co., Ltd., Hirisima. Pp. 743-1012.

Noguchi, A. 1994. Illustrated Moss Flora of Japan 5. Daigaku Printing Co., Ltd., Hirisima. Pp. 1013-1253.

Park, S. J. 2020. Moss flora of Korean Peninsula. PhD disserta- tion, Jeonbuk National University, Jeonju, Korea, 463 pp.

Song, J. S. and K. Yamada. 2009. Liverworts from Mt. Kaya (Gaya), South Korea. Journal of Phytogeography and Taxonomy 57: 35-38.

Söderström, L., A. Hagborg, M. von Konrat, S. BartholomewBegan, D. Bell, L. Briscoe, E. Brown, D. C. Cargill, D. P. Costa, B. J. Crandall-Stotler, E. D. Cooper, G. Dauphin, J. J. Engel, K. Feldberg, D. Glenny, S. R. Gradstein, X. He, J. Heinrichs, J. Hentschel, A. L. Ilkiu-Borges, T. Katagiri, N. A. Konstantinova, J. Larrain, D. G. Long, M. Nebel, T. Pôcs, F. Puche, E. Reiner-Drehwald, M. A. M. Renner, A. Sass-Gyarmati, A. Schâfer-Verwimp, J. G. S. Moragues, R. E. Stotler, P. Sukkharak, B. M. Thiers, J. Uribe, J. Váña, J. C. Villarreal, M. Wigginton, L. Zhang \& R.-L. Zhu. 2016. World checklist of hornworts and liverworts. PhytoKeys 59: 1-828.

Takhtajan, A. L. 1986. Floristic Regions of the World. University of California Press, Berkeley. Pp. 1-522.

Wu, P. C., M. R. Crosby and H. Si. 2002. Moss Flora of China, Vol. 6. Hookeriaceae-Thuidiaceae. Science Press, Beijing and Missouri Botanical Garden Press, St. Louis, MO, 221 pp.

Wu, P. C., M. R. Crosby and H. Si. 2005. Moss Flora of China, Vol. 8. Sematophyllaceae-Polytrichaceae. Science Press, Beijing and Missouri Botanical Garden Press, St. Louis, MO, 366 pp.

Wu, P. C., M. R. Crosby and H. Si. 2011. Moss Flora of China, Vol. 5. Erpodiaceae-Climaciaceae. Science Press, Beijing and Missouri Botanical Garden Press, St. Louis, MO, 423 pp.

Yim E.-Y. 2012. Flora of Bryophytes. In The Natural Resources Research in Mt. Hallasan. World Heritage Office, Jeju Special Self-Governing Provincial Government, Jeju, 587 pp. (in Korean)

Yoon, Y. J., C. H. Kim, K. V. Gorobets and B.-Y. Sun. 2011. The moss flora of Mt. Deogyu in Korea. Korean Journal of Plant Taxonomy 41: 287-297.

Zhu, R.-L. and M. L. So. 2001. Epiphyllous liverworts of China. Nova Hedwigia Beiheft 121: 1-418. 
Appendix 1. The list of Bryophytes in Gayasan Mountain. The nomenclature and arrangement of taxa are followed the system which is proposed by Goffinet et al. (2009) for mosses and Crandall-Stotler et al. (2009) and Söderström et al. (2016) for liverworts, everywhere with the recent updates. Newly recorded species for Gayasan Mountain are marked with asterisk $\left.{ }^{*}\right)$ in front of scientific names.

\begin{tabular}{|c|c|c|c|c|}
\hline Scientific name & Korean name & $\begin{array}{l}\text { Longitudinal } \\
\text { type }\end{array}$ & latitudinal type & Voucher No. \\
\hline Bryophyta & 선류식물문 & & & \\
\hline Andereaeaceae & 검정이끼과 & & & \\
\hline Andreaea rupestris var. fauriei (Besch.) Takaki. & 검정이끼 & Eastern Asia & Boreal & Park 16100993 \\
\hline Polytrichaceae & 솔이끼과 & & & \\
\hline *Atrichum rhystophyllum (Müll. Hal.) Paris & 아기주름솔이끼 & Eastern Asia & Temperate & Park 16111069 \\
\hline *Atrichum undulatum (Hedw.) P. Beauv. & 주름솔이끼 & Circumpolar & Temperate & Park 16100948 \\
\hline *Atrichum undulatum var. gracilisetum Besch. & 넓은주름솔이끼 & Circumpolar & Boreal-temperate & Yim-GYM284 \\
\hline *Pogonatum contortum (Menzies ex Brid.) Lesq. & 그늘들솔이끼 & $\begin{array}{l}\text { Eastern Asia- } \\
\text { American }\end{array}$ & Temperate & Park 16101023 \\
\hline Pogonatum inflexum (Lindb.) Lac. & 아기들솔이끼 & Eastern Asia & Temperate-subtropical & $\begin{array}{c}\text { Only literature } \\
\text { (Kashimura 1940) }\end{array}$ \\
\hline *Pogonatum neesii (Müll. Hal.) Doay. & 들솔이끼 & Eastern Asia & Temperate-subtropical & Park 16100953 \\
\hline *Pogonatum spinulosum Mitt. & 침들솔이끼 & $\begin{array}{c}\text { Eastern Asia- } \\
\text { American }\end{array}$ & Temperate-subtropical & Park 16100973 \\
\hline *Pogonatum urnigerum (Hedw.) P. Beauv. & 산들솔이끼 & Multiarea & Multizone & Park 16101021 \\
\hline Polytrichastrum alpinum (Hedw.) G. L. Sm & 산솔이끼 & Multiarea & Multizone & $\begin{array}{l}\text { Only literature } \\
\text { (Kashimura 1940) }\end{array}$ \\
\hline *Polytrichum formosum Hedw. & 큰솔이끼 & Multiarea & Temperate & Park 16100957 \\
\hline Diphysciaceae & 보리알이끼과 & & & \\
\hline *Diphyscium fulvifolium Mitt & 보리알이끼 & Eastern Asia & Temperate-subtropical & Park 16111064 \\
\hline *Diphyscium lorifolium (Cardot) Magombo & 곰이끼 & Asia & Temperate & Park 16111076 \\
\hline Funariaceae & 표주박이끼과 & & & \\
\hline *Funaria hygrometrica Hedw. & 표주박이끼 & Multiarea & Multizone & Park 16101020 \\
\hline Bryoxiphiaceae & 새우이끼과 & & & \\
\hline $\begin{array}{l}\text { Bryoxiphium norvegicum subsp. japonicum (Berggr.) Love. } \\
\text { \& Love. }\end{array}$ & 새우이끼 & Circumpolar & Temperate & Yim-GYM104 \\
\hline Grimmiaceae & 고깔바위이끼과 & & & \\
\hline *Grimmia pilifera P.Beauv. & 흰털고깔바위이끼 & Circumpolar & Boreal-temperate & Park 16111056 \\
\hline *Racomitrium canescens (Hedw.) Brid. & 서리이끼 & Circumpolar & Boreal-temperate & Park 16100963 \\
\hline *Racomitrium fasciculare (Hedw.) Brid. & 민서리이끼 & Multiarea & Multizone & Park 16100919 \\
\hline *Racomitrium heterostichum (Hedw.) Brid. & 검정서리이끼 & Circumpolar & Boreal-temperate & Park 1610098 \\
\hline *Racomitrium lanuginosum (Hedw.) Brid. & 된서리이끼 & Multiarea & Multizone & Park 1610095 \\
\hline *Schistidium apocarpum (Hedw.) Bruch. \& Schimp. & 고깔바위이끼 & Multiarea & Multizone & Park 16100998 \\
\hline Ptychomitriaceae & 곱슬이끼과 & & & \\
\hline *Ptychomitrium dentatum (Mitt.) A. Jaeger. & 물가곱슬이끼 & Eastern Asia & Temperate & Park 16111077 \\
\hline *Ptychomitrium linearifolium Reim. \& Sakurai. & 돌주름곱슬이끼 & Eastern Asia & Temperate & Yim-GYM004 \\
\hline *Ptychomitrium sinense (Mitt.) A. Jaeger. & 곱슬이끼 & Circumpolar & Boreal-temperate & Park 16100916 \\
\hline Fissidentaceae & 봉황이끼과 & & & \\
\hline *Fissidens gymnogynus Besch. & 작은봉황이끼 & Eastern Asia & Temperate & Park 16100922 \\
\hline
\end{tabular}


Appendix 1. Continued.

\begin{tabular}{|c|c|c|c|c|}
\hline Scientific name & Korean name & $\begin{array}{l}\text { Longitudinal } \\
\text { type }\end{array}$ & latitudinal type & Voucher No. \\
\hline *Fissidens teysmannianus Dozy \& Molk. & 아기봉황이끼 & Asia & Subtropical-tropical & Yim-GYM147 \\
\hline Bruchiaceae & 두루미이끼과 & & & \\
\hline *Trematodon longicollis Michx. & 두루미이끼 & Multiarea & Multizone & Park 16101020-1 \\
\hline Erpodiaceae & 나무연지이끼과 & & & \\
\hline *Venturiella sinensis (Venturi) Müll. Hal. & 나무연지이끼 & $\begin{array}{l}\text { Eastern Asia- } \\
\text { American }\end{array}$ & Temperate & Park 1610091 \\
\hline Rhabodoweisiaceae & 주름꼬마이끼과 & & & \\
\hline *Rhabdoweisia crispata (With.) Lindb. & 주름꼬마이끼 & Multiarea & Boreal-temperate & Park 16100994 \\
\hline Dicranaceae & 꼬리이끼과 & & & \\
\hline *Dicranella heteromalla (Hedw.) Schimp. & 억새이끼 & Circumpolar & Boreal-temperate & Park 16111074 \\
\hline *Dicranum flagellare Hedw. & 잎눈꼬리이끼 & Circumpolar & Boreal-temperate & Park 16100989 \\
\hline *Dicranum fuscescens Turner. & 갈색고산꼬리이끼 & Circumpolar & Boreal-temperate & Park 16101019 \\
\hline *Dicranum japonicum Mitt. & 꼬리이끼 & Eastern Asia & Temperate & Yim-GYM070 \\
\hline *Dicranum majus Turner. & 고산나무꼬리이끼 & Circumpolar & Boreal-temperate & Park 16101025 \\
\hline Leucobryaceae & 흰털이끼과 & & & \\
\hline *Brothera leana (Sull.) Müll. Hal. & 사자이끼 & Asia-American & Boreal-temperate & Park 16100966 \\
\hline *Campylopus sinensis (Müll. Hal.) J. P. Frahm & 붓이끼 & Amphipacific & Temperate & Park 16100907 \\
\hline *Leucobryum juniperoideum (Brid.) Müll. Hal. & 가는흰털이끼 & Circumpolar & Temperate & Park 16100950 \\
\hline Pottiaceae & 침꼬마이끼과 & & & \\
\hline *Bryoerythrophyllum recurvirostrum (Hedw.) P. C. Chen & 빨간담배잎이끼 & Circumpolar & Boreal-temperate & Yim-GYM285 \\
\hline *Weisiopsis anomala Broth. \& Paris & 겉꼬마이끼 & Eastern Asia & Temperate & Yim-GYM019 \\
\hline *Weissia controversa Hedw. & 꼬마이끼 & Multiarea & Multizone & Yim-GYM041 \\
\hline *Weissia crispa (Hedw.) Mitt. & 흙구슬이끼 & Circumpolar & Temperate & Yim-GYM061 \\
\hline Bryaceae & 참이끼과 & & & \\
\hline *Brachymenium exile (Dozy \& Molk.) Bosch \& Sande Lac & 가는참외이끼 & Multiarea & Subtropical-tropical & Park 16100945 \\
\hline *Brachymenium nepalense Hook. & 노란참외이끼 & Asia & Temperate-subtropical & Park 16100975 \\
\hline Bryum argenteum Hedw. & 은이끼 & Multiarea & Multizone & Park 16111051 \\
\hline *Bryum pseudotriquetrum (Hedw.) P. Gaertn. & 큰철사이끼 & Multiarea & Multizone & Yim-GYM286 \\
\hline *Rosulabryum capillare (Hedw.) J. R. Spence & 뱀밥철사이끼 & Multiarea & Multizone & Park 16100938 \\
\hline Mniaceae & 초롱이끼과 & & & \\
\hline *Mnium lycopodioides Schwägr. & 납작맥초롱이끼 & Circumpolar & Boreal-temperate & Park 1610096 \\
\hline *Mnium stellare Reichard ex Hedw. & 별꼴초롱이끼 & Circumpolar & Boreal-temperate & Park 16111061 \\
\hline Plagiomnium acutum (Lindb.) T. J. Kop. & 아기들덩굴초롱이끼 & Asia & Boreal-temperate & Yim-GYM100 \\
\hline *Plagiomnium cuspidatum (Hedw.) T. J. Kop. & 들덩굴초롱이끼 & Circumpolar & Boreal-temperate & Park 16100941 \\
\hline *Plagiomnium maximoviczii (Lindb.)T. J. Kop. & 덩굴초롱이끼 & Asia & Subtropical & Park 16111060 \\
\hline *Plagiomnium vesicatum (Besch.) T. J. Kop. & 큰잎덩굴초롱이끼 & Asia-Europe & Temperate & Yim-GYM112 \\
\hline *Pohlia proligera (Kindb.) Broth. & 흙들수세미이끼 & Circumpolar & Boreal-temperate & Park 16100994-1 \\
\hline *Rhizomnium punctatum (Hedw.) T. J. Kop. & 미선초롱이끼 & Circumpolar & Boreal-temperate & $\begin{array}{c}\text { Only literature } \\
\text { (Kashimura 1939) }\end{array}$ \\
\hline Rhizomnium striatulum (Mitt.) T. J. Kop. & 줄미선초롱이끼 & Asia & Boreal-temperate & Yim-GYM230 \\
\hline
\end{tabular}


Appendix 1. Continued.

\begin{tabular}{|c|c|c|c|c|}
\hline Scientific name & Korean name & $\begin{array}{l}\text { Longitudinal } \\
\text { type }\end{array}$ & latitudinal type & Voucher No. \\
\hline *Trachycystis flagellaris (Sull. \& Lesq.) Lindb. & 털아기초롱이끼 & $\begin{array}{l}\text { Eastern Asia- } \\
\text { American }\end{array}$ & Boreal-temperate & Yim-GYM287 \\
\hline *Trachycystis microphylla (Dozy \& Molk.) Lindb & 아기초롱이끼 & $\begin{array}{l}\text { Eastern Asia- } \\
\text { American }\end{array}$ & Subtropical & Park 16101030 \\
\hline *Trachycystis ussuriensis (Maack \& Regel) T. J. Kop. & 꼬인아기초롱이끼 & Asia-Europe & Boreal-temperate & Yim-GYM288 \\
\hline Bartramiaceae & 구슬이끼과 & & & \\
\hline *Philonotis falcata (Hook.) Mitt. & 낫물가이끼 & Multiarea & Temperate-subtropical & Park 16100933 \\
\hline *Philonotis fontana (Hedw.) Brid. & 물가이끼 & Multiarea & Multizone & Yim-GYM018 \\
\hline Hedwigiaceae & 톳이끼과 & & & \\
\hline Hedwigia ciliata (Hedw.) P. Beauv. & 톳이끼 & Multiarea & Multizone & Park 16100937 \\
\hline Hookeriaceae & 기름종이이끼과 & & & \\
\hline *Hookeria acutifolia Hook. \& Grev. & 기름종이이끼 & Multiarea & Temperate-subtropical & Yim-GYM289 \\
\hline Amlystegiaceae & 버들이끼과 & & & \\
\hline *Campyliadelphus chrysophyllus (Brid.) R.S.Chopra & 가는노란변덕이끼 & Circumpolar & Boreal-temperate & Park 1610099 \\
\hline Leskeaceae & 고깔검정이끼과 & & & \\
\hline *Haplocladium angustifolium (Hampe \& Müll. Hal.) Broth. & 침작은명주실이끼 & Multiarea & Temperate & Yim-GYM077 \\
\hline *Haplocladium microphyllum (Hedw.) Broth. & 작은명주실이끼 & Circumpolar & Multizone & Yim-GYM006 \\
\hline *Miyabea fruticella (Mitt.) Broth. & 꼬마나무이끼 & Eastern Asia & Temperate & Park 16111084 \\
\hline Thuidiaceae & 깃털이끼과 & & & \\
\hline Boulaya mittenii (Broth.) Cardot & 아기방울이끼 & Eastern Asia & Boreal-temperate & $\begin{array}{c}\text { Only literature } \\
\text { (Kashimura 1940) }\end{array}$ \\
\hline *Fauriella tenuis (Mitt.) Cardot & 수염이끼 & Eastern Asia & Temperate-subtropical & Park 16100944 \\
\hline *Pelekium versicolor (Hornsch. ex Müll. Hal.) Touw & 아기깃털이끼 & Asia & Subtropical-tropical & Yim-GYM024 \\
\hline *Thuidium kanedae Sakurai & 깃털이끼 & Eastern Asia & Temperate-subtropical & Park 16100931 \\
\hline Brachytheciaceae & 양털이끼과 & & & \\
\hline *Brachythecium buchananii (Hook.) A. Jaeger. & 긴양털이끼 & Eastern Asia & Temperate & Yim-GYM290 \\
\hline *Brachythecium helminthocladum Broth. \& Pari & 끈양털이끼 & Eastern Asia & Temperate & Yim-GYM080 \\
\hline *Brachythecium plumosum (Hedw.) Schimp. & 날개양털이끼 & Circumpolar & Multizone & Yim-GYM101 \\
\hline *Brachythecium populeum (Hedw.) Schimp. & 양털이끼 & Multiarea & Temperate & Park 16101009 \\
\hline *Brachythecium rivulare Schimp. & 물가양털이끼 & Circumpolar & Boreal-temperate & Yim-GYM291 \\
\hline *Bryhnia novae-angliae (Sull. \& Lesq.) Grout & 곱슬세모양털이끼 & Circumpolar & Boreal-temperate & Yim-GYM292 \\
\hline *Eurhynchium savatieri Schimp. ex Besch. & 가는부리이끼 & Eastern Asia & Temperate-subtropical & Yim-GYM020 \\
\hline *Homalothecium laevisetum Sande Lac. & 나뭇가지이끼 & Eastern Asia & Subtropical-tropical & Yim-GYM293 \\
\hline $\begin{array}{l}\text { Myuroclada maximowiczii (G. G. Borshch.) Steere \& W.B. } \\
\text { Schofield }\end{array}$ & 쥐꼬리이끼 & Circumpolar & Boreal-temperate & Yim-GYM108 \\
\hline *Okamuraea brachydictyon (Cardot) Nog. & 가는겉양털이끼 & Eastern Asia & Boreal-temperate & Yim-GYM294 \\
\hline *Okamuraea hakoniensis (Mitt.) Broth. & 겉양털이끼 & Asia & Boreal-temperate & Yim-GYM295 \\
\hline *Rhynchostegium pallidifolium (Mitt.) A. Jaeger & 아기양털부리이끼 & Eastern Asia & Temperate-subtropical & Yim-GYM296 \\
\hline *Rhynchostegium riparioides (Hedw.) Cardot & 물가부리이끼 & Circumpolar & Temperate-subtropical & Park 16100924 \\
\hline $\begin{array}{l}\text { Meteorium buchananii subsp. helminthocladulum (Cardot) } \\
\text { Nog. }\end{array}$ & 아기누운끈이끼 & Asia & Temperate-subtropical & $\begin{array}{l}\text { Only literature } \\
\text { (Kashimura 1940) }\end{array}$ \\
\hline
\end{tabular}


Appendix 1. Continued.

\begin{tabular}{|c|c|c|c|c|}
\hline Scientific name & Korean name & $\begin{array}{l}\text { Longitudinal } \\
\text { type }\end{array}$ & latitudinal type & Voucher No. \\
\hline Hypnaceae & 털깃털이끼과 & & & \\
\hline *Gollania ruginosa (Mitt.) Broth. & 주름사슴뿔이끼 & Asia & Boreal-temperate & Park 16101007 \\
\hline *Gollania varians (Mitt.) Broth. & 사슴뿔이끼 & Eastern Asia & Temperate & Park 1610101 \\
\hline *Hypnum oldhamii (Mitt.) A. Jaeger & 가는털깃털이끼 & Eastern Asia & Temperate-subtropical & Park 16100940 \\
\hline *Hypnum plumaeforme Wilson & 털깃털이끼 & Disjunctive & Temperate-subtropical & Park 1610095 \\
\hline *Hypnum tristo-viride (Broth.) Paris & 실털깃털이끼 & Eastern Asia & Temperate-subtropical & Park 16100991 \\
\hline $\begin{array}{l}\text { *Pseudotaxiphyllum pohliaecarpum (Sull. \& Lesq.) Z. } \\
\text { Iwats. }\end{array}$ & 빨간겉주목이끼 & Asia & Subtropical & Park 16111070 \\
\hline *Taxiphyllum aomoriense (Besch.) Z. Iwats. & 겹친주목이끼 & Eastern Asia & Boreal-temperate & Yim-GYM240 \\
\hline *Taxiphyllum taxirameum (Mitt.) M. Fleisch. & 주목이끼 & Asia-American & Subtropical-tropical & Yim-GYM057 \\
\hline Rhytidiaceae & 굵은이끼과 & & & \\
\hline Rhytidium rugosum (Hedw.) Kindb. & 굵은이끼 & Circumpolar & Boreal-temperate & $\begin{array}{l}\text { Only literature } \\
\text { (Kashimura 1940) }\end{array}$ \\
\hline Plagiotheciaceae & 산주목이끼과 & & & \\
\hline *Plagiothecium cavifolium (Brid.) Z. Iwats. & 둥근산주목이끼 & Circumpolar & Boreal-temperate & Park 16101008 \\
\hline *Plagiothecium euryphyllum (Cardot \& Thér.) Z. Iwats. & 넓은잎산주목이끼 & Eastern Asia & Boreal-temperate & Yim-GYM012 \\
\hline *Plagiothecium nemorale (Mitt.) A. Jaeger. & 산주목이끼 & Multiarea & Multizone & Park 16101006 \\
\hline Entodontaceae & 윤이끼과 & & & \\
\hline${ }^{*}$ Entodon challengeri (Paris) Cardot & 넓은잎윤이끼 & Circumpolar & Boreal-temperate & Park 16100918 \\
\hline Entodon flavescens (Hook.) A. Jaeger. & 가지윤이끼 & Asia & Boreal-temperate & Park 16100968 \\
\hline *Entodon luridus (Griff.) A. Jaeger. & 물가윤이끼 & Eastern Asia & Boreal-temperate & Park 16111059 \\
\hline *Entodon sullivantii (Müll. Hal.) Lindb. & 가는윤이끼 & $\begin{array}{l}\text { Eastern Asia- } \\
\text { American }\end{array}$ & Boreal-temperate & Yim-GYM054 \\
\hline Pylaisiadelphaceae & 털거울이끼과 & & & \\
\hline *Pylaisiadelpha tenuirostris (Bruch \& Schimp.) W.R. Buck & 털거울이끼 & Eastern Asia & Temperate-subtropical & Park 16111079 \\
\hline Sematophyllaceae & 무성아실이끼과 & & & \\
\hline *Sematophyllum subhumile (Müll. Hal.) M. Fleisch. & 무성아실이끼 & Asia & Subtropical-tropical & Yim-GYM065 \\
\hline Neckeraceae & 납작이끼과 & & & \\
\hline Homalia trichomanoides (Hedw.) Schimp. & 윤납작이끼 & Circumpolar & Boreal-temperate & Yim-GYM297 \\
\hline *Neckera humilis Mitt. & 납작이끼 & Eastern Asia & Temperate-subtropical & Yim-GYM298 \\
\hline $\begin{array}{l}\text { *Thamnobryum subseriatum (Mitt. ex Sande Lac.) } \\
\text { B.C.Tan. }\end{array}$ & 대호꼬리이끼 & Eastern Asia & Boreal-temperate & Yim-GYM299 \\
\hline Leptodontaceae & 방울이끼과 & & & \\
\hline *Forsstroemia trichomitria (Hedw.) Lindb. & 방울이끼 & $\begin{array}{l}\text { Eastern Asia- } \\
\text { American }\end{array}$ & Temperate & Yim-GYM082 \\
\hline Myuriaceae & 겉쥐꼬리이끼과 & & & \\
\hline Eumyurium sinicum (Mitt.) Nog. & 겉쥐꼬리이끼 & Eastern Asia & Subtropical-tropical & $\begin{array}{c}\text { Only literature } \\
\text { (Kashimura 1940) }\end{array}$ \\
\hline Anomodontaceae & 명주실이끼과 & & & \\
\hline Anomodon giraldii Müll. Hal. & 큰명주실이끼 & Eastern Asia & Boreal-temperate & Yim-GYM300 \\
\hline *Anomodon longifolius (Schleich. ex Brid.) Hartm. & 명주실이끼 & Asia & Boreal-temperate & Park 16111085 \\
\hline
\end{tabular}


Appendix 1. Continued.

\begin{tabular}{|c|c|c|c|c|}
\hline Scientific name & Korean name & $\begin{array}{l}\text { Longitudinal } \\
\text { type }\end{array}$ & latitudinal type & Voucher No. \\
\hline *Anomodon minor (Hedw.) Lindb. & 푸른명주실이끼 & Asia-American & Boreal-temperate & Park 16100930 \\
\hline Anomodon rugelii (Müll. Hal.) Keissl. & 곱슬명주실이끼 & Circumpolar & Boreal-temperate & Yim-GYM130 \\
\hline *Haplohymenium pseudo-triste (Müll. Hal.) Broth. & 꼬마바위실이끼 & Amphioceanic & Boreal-temperate & Park 16100984 \\
\hline *Herpetineuron toccoae (Sull. \& Lesq.) Cardot & 나선이끼 & Asia-American & Subtropical-tropical & Park 16111080 \\
\hline *Schwetschkeopsis fabronia (Schwagr.) Broth. & 개털이끼 & $\begin{array}{l}\text { Eastern Asia- } \\
\text { American }\end{array}$ & Temperate & Park 16111086 \\
\hline *Schwetschkeopsis robustula (Broth.) Ando & 큰개털이끼 & Eastern Asia & Temperate & Park 16100926 \\
\hline Marchantiophyta & 태류식물문 & & & \\
\hline Aytoniaceae & 삿갓우산이끼과 & & & \\
\hline *Reboulia hemisphaerica (L.) Raddi & 삿갓우산이끼 & Multiarea & Multizone & Choi 161194 \\
\hline Conocephalaceae & 패랭이우산이끼과 & & & \\
\hline Conocephalum salebrosum Szweyk., Buczk. et Odrzyk. & 패랭이우산이끼 & Circumpolar & Boreal & Choi 161180 \\
\hline${ }^{*}$ Conocephalum japonicum (Thunb.) Grolle & 아기패랭이우산이끼 & Eastern Asia & Multizone & Choi 161195 \\
\hline Pelliaceae & 물우산대이끼과 & & & \\
\hline *Apopellia endiviifolia (Dicks.) Nebel et D.Quandt & 가는물우산대이끼 & Circumpolar & Boreal & Yim-GYM301 \\
\hline Metzgeriaceae & 리본이끼과 & & & \\
\hline *Metzgeria lindbergii Schiffn. & 리본이끼 & Multiarea & Multizone & Yim-GYM163 \\
\hline *Metzgeria temperata Kuwah. & 무성아리본이끼 & Amphioceanic & Temperate-subtropical & Choi 161300 \\
\hline Aneuraceae & 초록우산대이끼과 & & & \\
\hline *Aneura maxima (Schiffner) Steph. & 큰초록우산대이끼 & Multiarea & Multizone & Choi 161181 \\
\hline Porellaceae & 세줄이끼과 & & & \\
\hline $\begin{array}{l}\text { Porella caespitans var. cordifolia (Steph.) S. Hatt. ex T. } \\
\text { Katag. et T. Yamag. }\end{array}$ & 침세줄이끼 & Asia & Temperate-subtropical & $\begin{array}{l}\text { Only literature } \\
\text { (Hong 1966) }\end{array}$ \\
\hline Porella grandiloba Lindb. & 큰세줄이끼 & Eastern Asia & Temperate-subtropical & Choi 161223 \\
\hline Porella ulophylla (Steph.) S. Hatt. & 주름세줄이끼 & Eastern Asia & Temperate-subtropical & Choi 161191 \\
\hline Porella vernicosa Lindb. & 가시세줄이끼 & Eastern Asia & Temperate-subtropical & Yim-GYM302 \\
\hline Radulaceae & 부채이끼과 & & & \\
\hline *Radula auriculata Steph. & 귀부채이끼 & Amphipacific & Boreal-temperate & Choi $161267 \mathrm{a}$ \\
\hline *Radula cavifolia Hampe & 큰잎부채이끼 & Asia & Subtropical-tropical & Choi 161242 \\
\hline Radula constricta Steph. & 무성아부채이끼 & Eastern Asia & Boreal-temperate & Choi 161268 \\
\hline *Radula japonica Gottsche & 부채이끼 & Eastern Asia & Temperate-subtropical & Choi 161198 \\
\hline Radula oyamensis Steph. & 처녀부채이끼 & Eastern Asia & Temperate-subtropical & $\begin{array}{c}\text { Only literature } \\
\text { (Song \& Yamada } \\
\text { 2009) }\end{array}$ \\
\hline Frullaniaceae & 지네이끼과 & & & \\
\hline Frullania aoshimensis Horik. & 가야지네이끼(신칭) & Eastern Asia & Temperate & $\begin{array}{c}\text { Only literature } \\
\text { (Song \& Yamada } \\
\text { 2009) }\end{array}$ \\
\hline Frullania appendiculata Steph. & 침지네이끼 & Eastern Asia & Temperate-subtropical & Choi 161314 \\
\hline Frullania ericoides (Nees ex Mart.) Mont. & 초록지네이끼 & Circumpolar & Subtropical-tropical & $\begin{array}{c}\text { Only literature } \\
\text { (Song \& Yamada } \\
\text { 2009) }\end{array}$ \\
\hline
\end{tabular}


Appendix 1. Continued.

\begin{tabular}{|c|c|c|c|c|}
\hline Scientific name & Korean name & $\begin{array}{l}\text { Longitudinal } \\
\text { type }\end{array}$ & latitudinal type & Voucher No. \\
\hline Frullania davurica Hampe & 빨간지네이끼 & Asia & Boreal-temperate & Choi 161252 \\
\hline Frullania densiloba Steph. & 가는지네이끼 & $\begin{array}{c}\text { Eastern Asia- } \\
\text { American }\end{array}$ & Subtropical & Choi $161205 a$ \\
\hline Frullania diversitexta Steph. & 지네이끼 & Eastern Asia & Subtropical & $\begin{array}{l}\text { Only literature } \\
\text { (Hong 1966) }\end{array}$ \\
\hline Frullania inflata Gottsch. & 물가지네이끼 & Asia-American & Temperate-subtropical & $\begin{array}{l}\text { Only literature } \\
\text { (Hong 1966) }\end{array}$ \\
\hline Frullania muscicola Steph. & 참지네이끼 & Asia & Temperate & Choi 161185 \\
\hline Frullania parvistipula Steph. & 종지네이끼 & Asia-Europe & Temperate-subtropical & $\begin{array}{c}\text { Only literature } \\
\text { (Song \& Yamada } \\
\text { 2009) }\end{array}$ \\
\hline *Frullania pedicellata Steph. & 검정지네이끼 & Eastern Asia & Subtropical & Choi 4342 \\
\hline *Frullania schensiana C. Massal. & 산지네이끼 & Eastern Asia & Temperate-subtropical & Choi 161190 \\
\hline Frullania taradakensis Steph. & 들지네이끼 & Eastern Asia & Subtropical & Choi 161196 \\
\hline Frullania usamienesis Steph. & 우사미지네이끼 & Eastern Asia & Temperate & Choi 161262 \\
\hline Jubulaceae & 가시지네이끼과 & & & \\
\hline *Nipponolejeunea pilifera (Steph.) S. Hatt. & 긴털귀이끼 & Eastern Asia & Boreal-temperate & Choi 161299a \\
\hline Lejeuneaceae & 작은귀이끼과 & & & \\
\hline Acrolejeunea pusilla (Steph.) Grolle \& Gradst. & 사슴주름이끼 & Eastern Asia & Boreal-temperate & $\begin{array}{c}\text { Only literature } \\
\text { (Song \& Yamada } \\
\text { 2009) }\end{array}$ \\
\hline *Cheilolejeunea obtusifolia (Steph.) S. Hatt. & 아기사슬이끼 & Eastern Asia & Temperate & Choi 161201 \\
\hline Cololejeunea japonica (Schiffn.) Mizut. & 세모귀이끼 & Eastern Asia & Subtropical & $\begin{array}{c}\text { Only literature } \\
\text { (Song \& Yamada } \\
\text { 2009) }\end{array}$ \\
\hline *Cololejeunea longifolia (Mitt.) Benedix & 긴귀이끼 & Eastern Asia & Temperate-subtropical & Choi 161200 \\
\hline *Dicranolejeunea yoshinagana (S. Hatt.) Mizut. & 검정비늘이끼 & Eastern Asia & Temperate-subtropical & Choi 161183 \\
\hline *Drepanolejeunea angustifolia (Mitt.) Grolle & 칼잎이끼 & Eastern Asia & Subtropical & Choi 161247 \\
\hline Lejeuena discreta Lindb. & 낫작은귀이끼 & Eastern Asia & Subtropical & $\begin{array}{c}\text { Only literature } \\
\text { (Song \& Yamada } \\
\text { 2009) }\end{array}$ \\
\hline Lejeuena japonica Mitt. & 작은귀이끼 & Eastern Asia & Temperate-subtropical & Choi $161187 b$ \\
\hline *Lejeuena otiana $\mathrm{S}$. Hatt. & 동굴작은귀이끼 & Eastern Asia & Subtropical & Choi 161182 \\
\hline Lejeuena parva (S. Hatt.) Mizut. & 들작은귀이끼 & Eastern Asia & Temperate-subtropical & $\begin{array}{c}\text { Song \& Yamada } \\
2009\end{array}$ \\
\hline Lejeuena ulicina (Taylor) Gottsche & 아기작은귀이끼 & Asia-Europe & Subtropical & Choi $161205 b$ \\
\hline Acrolejeunea sandvicensis (Gottsche) Steph. & 둥근귀이끼 & Circumpolar & Temperate-subtropical & Choi 161186 \\
\hline Herbertaceae & 쌍갈고리이끼과 & & & \\
\hline Herbertus aduncus (Dicks.) Gray & 쌍갈고리이끼 & Asia-American & Arctic-boreal & Choi $161299 b$ \\
\hline Lepidoziaceae & 벼슬이끼과 & & & \\
\hline *Bazzania denudata (Torr. ex Lindenb.) Trevis. & 산좀벼슬이끼 & Eastern Asia & Temperate & Choi 161311 \\
\hline Neotrichocoleaceae & 털이끼과 & & & \\
\hline Trichocoleopsis sacculata (Mitt.) S. Okamura & 가시잎이끼 & Eastern Asia & Temperate & Choe 1975 \\
\hline
\end{tabular}


Appendix 1. Continued.

\begin{tabular}{|c|c|c|c|c|}
\hline Scientific name & Korean name & $\begin{array}{l}\text { Longitudinal } \\
\text { type }\end{array}$ & latitudinal type & Voucher No. \\
\hline Lophocoleaceae & 두끝벼슬이끼과 & & & \\
\hline *Chiloscyphus pallescens (Ehrh. ex Hoffm.) Dumort. & 아기물비늘이끼 & Circumpolar & Boreal & Yim-GYM303 \\
\hline Chiloscyphus polyanthos (L.) Corda & 물비늘이끼 & Circumpolar & Boreal & Choi 161222 \\
\hline Heteroscyphus planus (Mitt.) Schiffn. & 비늘이끼 & Eastern Asia & Subtropical & Yim-GYM113 \\
\hline Lophocolea heterophylla (Schrad.) Dumort. & 두끝벼슬이끼 & Circumpolar & Boreal & $\begin{array}{l}\text { Only literature } \\
\text { (Hong 1966) }\end{array}$ \\
\hline Lophocolea minor Nees & 아기두끝벼슬이끼 & Circumpolar & Arctic-boreal & Yim-GYM304 \\
\hline Plagiochilaceae & 날개이끼과 & & & \\
\hline Pedinophyllum truncatum (Steph.) Inoue & 누운날개이끼 & Eastern Asia & Temperate & Choi 161302 \\
\hline Plagiochila hakkodensis Steph. & 빗타날개이끼 & Eastern Asia & Boreal-temperate & $\begin{array}{l}\text { Only literature } \\
\text { (Choe 1975) }\end{array}$ \\
\hline Plagiochila ovalifolia Mitt. & 둥근날개이끼 & Eastern Asia & Temperate-subtropical & Choi 161189 \\
\hline Plagiochila porelloides (Torrey) Lindenb. & 숲날개이끼 & Circumpolar & Arctic-boreal & Choi 161293 \\
\hline *Plagiochila sciophylla Nees & 아기날개이끼 & Asia & Subtropical & Choi 161184 \\
\hline Xenochila integrifolia (Mitt.) Inoue & 세모날개이끼 & Eastern Asia & Temperate & $\begin{array}{c}\text { Only literature } \\
\text { (Song \& Yamada } \\
\text { 2009) }\end{array}$ \\
\hline Jamesoniellaceae & 가을비늘이끼과 & & & \\
\hline $\begin{array}{l}\text { Syzygiella autumnalis (DC.) K. Feldberg, Ván̆a, Hentschel } \\
\text { et Heinrichs }\end{array}$ & 가을비늘이끼 & Circumpolar & Temperate & Choi 161296 \\
\hline Cephaloziaceae & 게발이끼과 & & & \\
\hline *Cephalozia otaruensis Steph. & 게발이끼 & Amphipacific & Boreal & Yim-GYM305 \\
\hline Cephaloziellaceae & 겉게발이끼과 & & & \\
\hline Cephaloziella divaricata (Sm.) Warnst. & 들겉게발이끼 & Circumpolar & Arctic & Choi 161296 \\
\hline${ }^{*}$ Cephaloziella hampeana (Nees) Schiffn. ex Leske & 산겉게 발이끼 & Circumpolar & Boreal & Choi 161207 \\
\hline *Cephaloziella microphylla (Steph.) Douin & 세모겉게 발이끼 & Eastern Asia & Temperate & Choi 161227 \\
\hline Cephaloziella spinicaulis Douin & 가시겉게 발이끼 & Asia-American & Temperate & $\begin{array}{l}\text { Only literature } \\
\text { (Hong 1966) }\end{array}$ \\
\hline *Cylindrocolea recurvifolia (Steph.) Inoue & 물겉게발이끼 & Eastern Asia & Temperate & Choi 161204 \\
\hline Scapaniaceae & 엄마이끼과 & & & \\
\hline *Diplophyllum albicans (L.) Dumort. & 흰긴엄마이끼 & Amphioceanic & Arctic & Choi 161210 \\
\hline *Scapania ampliata Steph. & 큰엄마이끼 & Eastern Asia & Arctic-boreal & Choi $161234 \mathrm{a}$ \\
\hline *Scapania ciliata Sande Lac. & 털엄마이끼 & Eastern Asia & Boreal & Choi 161309a \\
\hline${ }^{*}$ Scapania integerrima Steph. & 들엄마이끼 & Eastern Asia & Temperate & Choi $161257 \mathrm{a}$ \\
\hline *Scapania parvitexta Steph. & 배루카엄마이끼 & Eastern Asia & Boreal-temperate & Choi $161262 b$ \\
\hline *Scapania undulata (L.) Dumort. & 자주엄마아끼 & Circumpolar & Arctic-boreal & Choi 161319 \\
\hline Lophoziaceae & 갈래잎이끼과 & & & \\
\hline *Hattoria yakushimensis (Horik.) R. M. Schust. & 하늘이끼 & Eastern Asia & Temperate & Choi 161230 \\
\hline *Plicanthus birmensis (Steph.) R. M. Schust. & 단풍이끼 & Eastern Asia & Subtropical-tropical & Choi $161202 \mathrm{a}$ \\
\hline Calypogeiaceae & 목걸이이끼과 & & & \\
\hline Calypogeia arguta Nees \& Mont. ex Nees & 아기목걸이이끼 & Amphipacific & Temperate & Choi 161301b \\
\hline
\end{tabular}


Appendix 1. Continued.

\begin{tabular}{|c|c|c|c|c|}
\hline Scientific name & Korean name & $\begin{array}{l}\text { Longitudinal } \\
\text { type }\end{array}$ & latitudinal type & Voucher No. \\
\hline *Calypogeia tosana (Steph.) Steph. & 들목걸이이끼 & Eastern Asia & Temperate & Choi 161322 \\
\hline Delavayellaceae & 꼭지망울이끼과 & & & \\
\hline *Liochlaena subulata (A. Evans) Schljakov & 꼭지망울이끼 & Circumpolar & Boreal-temperate & Choi $161187 \mathrm{a}$ \\
\hline Jungermanniaceae & 망울이끼과 & & & \\
\hline *Jungermannia atrovirens Dumort. & 암록망울이끼 & Circumpolar & Arctic & Choi 4353 \\
\hline Jungermannia exsertifolia Steph. & 심장형망울이끼 & Circumpolar & Arctic & $\begin{array}{l}\text { Only literature } \\
\text { (Hong 1966) }\end{array}$ \\
\hline Solenostomataceae & 둥근망울이끼과 & & & \\
\hline *Nardia assamica (Mitt.) Amakawa & 빨간비늘이끼 & Eastern Asia & Arctic-boreal & Choi 4336 \\
\hline *Plectocolea erecta Amakawa & 곧은망울이끼 & Eastern Asia & Temperate & Choi 161249 \\
\hline *Plectocolea infusca Mitt. & 큰망울이끼 & Eastern Asia & Temperate-subtropical & Choi $161267 b$ \\
\hline *Plectocolea ovalifolia (Amakawa) Bakalin \& Vilnet & 누운큰망울이끼 & Eastern Asia & Boreal-temperate & Choi 7429 \\
\hline *Plectocolea rosulans (Steph.) S. Hatt. & 망울이끼 & Eastern Asia & Temperate-subtropical & Yim-GYM184 \\
\hline *Plectocolea truncata (Nees) Bakalin & 들망울이끼 & Eastern Asia & Temperate-subtropical & Choi 161258 \\
\hline Protosolenostoma fusiforme (Steph.) Vilnet \& Bakalin & 방추형망울이끼 & Eastern Asia & Boreal-temperate & $\begin{array}{c}\text { Only literature } \\
\text { (Song \& Yamada } \\
\text { 2009) }\end{array}$ \\
\hline *Solenostoma pyriflorum Steph. & 둥근망울이끼 & Asia & Arctic-boreal & Choi $161264 a$ \\
\hline *Solenostoma rotundatum Amakawa & 산망울이끼 & Eastern Asia & Temperate-subtropical & Choi 4355 \\
\hline *Solenostoma sunii Bakalin \& Vilnet & 선망울이끼 & Eastern Asia & Temperate & Choi 7415 \\
\hline Gymnomitriaceae & 은비늘이끼과 & & & \\
\hline *Marsupella pseudofunkii S. Hatt. & 가는양끝통이끼 & Eastern Asia & Temperate & Choi 161309b \\
\hline *Marsupella tubulosa Steph. & 양끝통이끼 & Circumpolar & Arctic-boreal & Choi 161317 \\
\hline *Marsupella yakushimensis Steph. & 산양끝통이끼 & Eastern Asia & Temperate & Yim-GYM306 \\
\hline
\end{tabular}

